\title{
Law Enforcement of Criminal Defamation Through Electronic Media
}

\section{Septavela Gusti Putri}

University of Jember, Indonesia

septavelagustiputri@gmail.com

\section{Echwan Irianto}

University of Jember, Indonesia

echwaniriyanto62@yahoo.com

\section{Dodik Prihatin AN}

University of Jember, Indonesia

dodik_page.fh@unej.ac.id

\section{ABSTRACT}

Defamation through Electronic Media as regulated in Article 27 paragraph (3) of Law No. 19 of 2016 on amendments to Law No. 11 of 2008 on Information and Electronic Transactions does not explain in detail the element of "insulting content and/or defamation;" therefore, the understanding of this term is subjective to the victim. Article 27 also includes the phrase "no rights," suggesting that victims' legal rights in response to defamation are limited. Even so, the Information and Electronic Transactions Law (ITE Law - Undang-Undang Informasi dan Transaksi Elektronik) itself does not provide a detailed explanation of these elements. The results found in this study are an objective criteria to assess whether electronic information or electronic documents which can be qualified as defaming. This study argues that defamation occurs if: (a) information or documents are built based on the clarity of the insulted person's identity; (b) the purpose of words is deemed insulting; (c) defamation is addressed to natural person or legal person (d) the content and context of each case, and (e) the allegations. In addition, a person is said to have the right to commit criminal defamation if carried out in the public interest and by being forced to defend himself.

KEYWORDS: Criminal Defamation, Electronic Media, Indonesia.

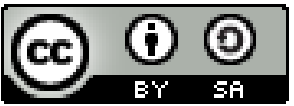

Copyright $\odot 2019$ by Author(s)

This work is licensed under a Creative Commons Attribution-ShareAlike 4.0 International License. All writings published in this journal are personal views of the authors and do not represent the views of this journal and the author's affiliated institutions.

\section{HOW TO CITE:}

Putri, Septavela Gusti Echwan Irianto \& Dodik Prihatin AN. "Law Enforcement of Criminal Defamation Through Electronik Media" (2019) 6:2 Lentera Hukum 267-278. 


\section{INTRODUCTION}

Like technological developments, criminal acts of defamation are not only done conventionally, but are also carried out through electronic media. In adjusting developments, regulated technological legal protection is against victims of criminal defamation committed through electronic media as written in Article 27 paragraph (3) of Act Number 19 of 2016, concerning Information and Electronic Transactions Law (ITE Law). But the element of "insulting content and/or defamation" contained in the article is subject to interpretation. This introduces a paradox where certain phrases which are considered defamation for one speaker may not necessarily be considered defamation for other speakers. R. Soesilo, touches on this topic in his book entitled the Criminal Code (KUHP - Kitab Undang-Undang Hukum Pidana), where he does not write the word "defamation" but uses the nomenclature "Attacking the Honor and Good Name of Someone". 1

Based on the Decision of the Constitutional Court Number 50/PUU-VI/2008 the interpretation of norms in Article 27 Paragraph (3) of the ITE Law cannot be separated from Article 310 and Article 311 of the Criminal Code. The ruling states that Article 27 paragraph (3) of the ITE Law does not regulate the norms of new criminal law, but only emphasizes the enactment of criminal acts of defamation that have been regulated in the Criminal Code. Thus, both interpretation and justification in Article 27 paragraph (3) of the ITE Law must refer to Article 310 and 311 of the Criminal Code. Wirjono Prodjodikoro introduces the nuances held within these codes. For example, Prodjodikoro asserts that what is meant by an attack (aanranden) is not physical, because what is attacked (the object) is a feeling about someone's honor and reputation. Prodjodikoro concludes that the measure for harm is self-esteem. The meaning of the attack here is to convey the words (words / sequences of words / sentences) by accusing them of committing certain actions aimed at the honor and good name of the person, which can result in a sense of self-worth or dignity of that person being debased. ${ }^{2}$

\section{THE CRITERIA TO QUALIFY CRIMINAL DEFAMATION THROUGH ELECTRONIC MEDIA}

The process of debasing is susceptible to multiple interpretations; this is showcased the variety of statements made by Indonesian jurists. Prodjodikoro further delineates another requirement: in order for someone to have their sense of honor debased, he or she must have the capacity to feel offense. For example, very young children and mentally compromised people cannot feel offended and there is hence no crime committed against either person.. ${ }^{3}$ Oemar Seno Adji defines defamation as attacking honor or good name (aanranding of geode naam) carried out by accusing something. ${ }^{4}$ Adami Chazawi defines humiliation as an attack on the dignity, honor, and good name of a person who is both personal and communal, which causes feelings of shame, offense, contamination, humiliation, giving birth to displeasure, hatred, dissatisfaction, a suffering that tortures the other person's mind. ${ }^{5}$ Whereas Satochid Kertanegara

\footnotetext{
Skripsi Fakultas Hukum Unhas, "Tinjauan Yuridis terhadap Tindak Pidana Penghinaan” (2014).

Adami Chazawi, Hukum Pidana Positif Penghinaan (Edisi Revisi) (Malang: Media Nusa Creative, 2016).

Wirjono Prodjodikoro, Tindak Pidana Tertentu di Indonesia (Bandung: Refika Aditama, 2003).

Skripsi Fakultas Hukum Unhas, supra note 1.

Adami Chazawi, supra note 2 at iii.
} 
defines defamation as invading human dignity or human honor. ${ }^{6}$ A good name that is objective, as said by Satochid Kertanegara, a good name is directed towards people who have a high position in society. Even though according to Kertanegara, this is not entirely true, but it is acceptable that in a high position it must be based on good personality (personal qualities), not because of high social position (including economics).

Though experts still contradict the meaning of honor and good name, they agree that honor and good name are the human rights of every human being. Criteria that are more objective in assessing an electronic document that can be considered an insult and/or defamation can be built based on following indicators.

\section{A. The Clarity of Personal Details of Insulted Persons in Information Electronic Documents}

In the defamation context, there must be clarity on the identity of the person who is insulted. Not to people in general, or to a group of people based on ethnicity, religion, race or class. Identifying information can be in the form of images (photos), usernames, curriculum vitae, or other information related to the particular person in question. ${ }^{7}$ It must be clear that the words are intended for the person (victim) and not others because the essence of defamation - as established in the previous section - is to attack the honor of others so that it is known to the public. Some cases regarding the lack of clarity of identifying information are as follows.

\section{The case of Yusniar (Decision Number 1933/Pid.Sus/2016/PN.Mks)}

This case stems from a Facebook status posted by Yusniar on March 14, 2016, which reads: "Alhamdulillah, akhirnya selesai juga masalahnya. Anggota DPR tolol (bodoh dalam bahasa Makassar), pengacara tolo (bodoh), mau nabantu (membantu) orang yang bersalah nyata-nyatanya tanahnya ortuku. Pegiko ganggu-ganggui poeng." In its ruling process, the panel of judges acquitted the defendant of all lawsuits, because elements of the content of insult and/or defamation were not fulfilled. Based on several statements from expert witnesses presented, the status was not addressed to the witness, Sudirman Sijaya, because the words "DPR members" on Facebook were not specifically addressed to this entity..

\section{The case of Khairuddin M. Ali (Decision Number 292/Pid.B/2014/PN.Rbi)}

The absence of a direct mention of the also happened to the defendant on behalf of Khairuddin M. Ali. On March 14, 2013 at 14.00 WITA, the defendant posted a comment, "the Election Supervisory Committee considered the Chairman of the Bima KPU General Commission violated the principle of Professionalism in carrying out their duties." Then on March 27, 2013, at 04.52 WITA commented "the decision to replace the chairman was the result of a plenary session by the Election Supervisory Committee. Committing ethical violations, the constitutional duties of the Election Supervisory Committee are indeed such a matter of conditions outside of other matters, instead we think that if they are not replaced they will continue to issue wrong decisions

\footnotetext{
Ibid at 5 .

Joshua Sitompul, Cyberspace, cybercrimes, cyberlaw (Jakarta: PT Tata Nusa, 2012).

Aditya Fajar Indrawan, "Pengacara keberatan dengan dakwaaan JPU: Posan Yusniar tak sebut nama orang”, (13 July 2018), online: <diakses dari https://news.detik.com/berita/d-3341329/pengacarakeberatan-dengan-dakwaan-jpu-posan-yusniar-tak-sebut-nama-orang>.
} 
through a wrong mechanism and violate the law, we also consider the results of clarification with all members of the City KPU Bima, so it is not necessarily without consideration, but I still appreciate any differences in views about this matter, our goal must be the same, to build a beloved region. "

In the decision, the panel of judges stated that Defendant Ir. Khairuddin M. Ali. M.Ap was not legally proven, nor was he convincingly guilty of committing a criminal act as charged on the first and second charges. In their consideration, the panel of judges stated that the element of insulting content and/or defamation was not fulfilled, written as follows:

"Considering, after the Panel of Judges examined the defendant's comments as mentioned above, the Defendant never mentioned the witness's name Dra. Nurfarhati, M.Sc and the Defendant also never attacked the good name of witness Dra. Nurfarhati M.si. by accusing something. Thus, the electronic document does not have an insulting content and/or defamation. Thus this element is not fulfilled by the defendant's actions. " 9

\section{The Case of Niam Sovie (Decision Number 441/Pid.Sus/2017/PT .Sby)}

In this case, Niam Sovie was the Village Chief (Kades) in Sumber Gedang, Pandaan District, Pasuruan Regency. At first, he posted his hopes for his village's development on his Facebook account. After that, there were some people who commented on their status. ${ }^{10}$ From some comments, there was a resident who asked about a damaged road, even though it had just been built. Niam Sovie replied to these comments which escalated into a caustic argument between himself and other posters. In his comments, the Defendant (Niam Sovie) mentioned the word "Ruler Before Me". On June 7, 2017 Decision Number 48/Pid.Sus/2017/PN.Bil had sentenced Niam Sovie to five months in prison for being found to have violated Article 27 paragraph (3) of the Electronic and Information Law. Then at the appeal level Decision Number 441/Pid.Sus/2017/PT.Sby revoked all the decisions of the Bangil District Court. This is because there is no direct and specific mention of the name contained in the word "Previous Ruler".

\section{B. Defamation Addressed to Natural Person and Legal Person}

According to Joshua Sitompul, defamation as written in the Criminal Code is directed at individuals (natural person) and not legal entities (legal person). A legal person may not have feelings of humiliation or their good names as tainted, given the legal person is a legal abstraction. Although the legal person is represented by official management or representative, the offense can only be directed to the person, just like murder or persecution where it is impossible for legal entities to be killed or persecuted literally. ${ }^{12}$ The Supreme Court recognized a legal person as the object of defamation equal to the individual, as stated in Decision No. 183K/PID/2010 as follows:

\footnotetext{
9 Anggara, Asep Komarudin \& Supriadi Widodo Eddyono, Menimbang Ulang Pasal 27 ayat (3) UU ITE dalam putusan pengadilan (Jakarta: Institute for Criminal Justice Reform (ICJR), 2016).

10 Warta Bromo, Sempat Diputus Bersalah, Kades Sumbergedang Bebas dalam Dugaan Pencemaran Nama Baik di FB. Diakses dari https://kumparan.com/wartabromo/sempat-diputus-bersalah-kades-sumbergedangbebas-dalam-dugaan-pencemaran-nama-baik-di-fb accessed on 13 July 2018 at 07.12

ll WartaBromo, "Sempat Diputus Bersalah, Kades Sumbergedang Bebas dalam Dugaan Pencemaran Nama Baik di FB", (13 July 2018), online: 〈https://kumparan.com/wartabromo/sempat-diputus bersalah-kades-sumbergedang-bebas-dalam-dugaan-pencemaran-nama-baik-di-fb).

12 Joshua Sitompul, supra note 8 at 179.
} 
"Whereas in this case, the object defamation is a Legal Entity of PT. Duta Pertiwi who is the main Director is Mr. Mukhtar Wijaya; "

"That as a reporter for these crimes the contaminated party is PT. Duta Pertiwi so that the reporter should be the Managing Director of PT. This is because the President Director represents PT. Duta Pertiwi; " ${ }^{13}$

Defamation aimed at legal entities has occurred in the case of Prita Mulyasari (Decision Number 1269/Pid.B/2009/PN.Tng). In other cases, defamation of legal entities also occurred in 2017 by Komika Acho. As previously explained, Acho complained about the services of the Green Pramuka Apartment through electronic media. In this case Acho was named a suspect because he was considered to have defamed the Legal Entity.

\section{The Content of the Defamation in Context}

This sense of honor must materialize in such a way that there is no uncertainty on whether an individual has the capacity to feel offended. It can be said that children who are very young cannot feel offended and that insane people cannot feel offended, thus there is no crime against both types of people. ${ }^{14}$ Objectively, based on context assessment, several cases are as follows.

\section{The case A. Hamidy Arsa (Decision Number 23/Pid.B /2011/PN.Jth)}

In the case of A. Hamidy Arsa, the judge was of the opinion that defamation was assessed based on the assessment of society to someone. It was outlined:

"By taking into account that what is meant by humiliation and/or defamation is to attack someone's honor and good name. While what is meant to attack one's reputation is to damage the good judgment of the community to someone. "

\section{The case of Ervani Emy (Decision Number 196/Pid.Sus/2014/PN.Btl)}

On 30 May 2014 Defendant Ervani Emy wrote the status on her Facebook, "Yes, indeed, Mr. Har is good, the one who is not good is the name Ayas and other Spv ... We think he does not deserve to be the leader of Jolie Jogja Jewelry. Lots of people are still like kids." In this case, the Panel of Judges stated that the words on Ervani Emy's status could not be qualified for defamation because the word lebay was a new vocabulary word, as something excessive and included only soft criticism. Written as follows:

"Considering, that in the opinion of the expert Dr. Aprinus Salam, M.Hum, the defendant's status on Facebook as complaining include on it the criticism there is no statement leading to defamation even though in his status Ervani Emy mentions someone's name is an ordinary criticism, the word lebay is a new vocabulary called slang language which is interpreted by young people now as something that is too excessive whose usual connotation and according to experts that soft criticism is only a matter of language choice and the use of these words does not violate ethics."

"Considering, that in the opinion of expert Dr.Muhammad Arif Setiawan SH, MH criminal law does not specifically protect a person and in criminal law does not specifically provide which criteria are permissible and which words should not be written."

Language and habit assessment, living in the community must also adjust to the times. For example, in the case of Ervani Emy (Decision Number 196/Pid.sus/ 2014/PN.Btl). As

13 Mahrus Ali, "Pencemaran Nama Baik melalui Sarana Informasi dan Transaksi Elektronik (Kajian Putusan MK No. 2/PUU-VII/2009”, (2010) Volume 07 Issue 06.

14 Wirjono Prodjodikoro, supra note 3 at 98. 
described above, in this case the defendant wrote the word "lebay" addressed to someone. The word 'lebay' is not written in KBBI (Big Indonesian Dictionary) because the word is a new vocabulary word that lives in the community and is often used by young people today which means "excessive".

\section{A. Accusing a Certain Action}

The alleged offender must be a certain actor that is coupled with an offensive act. Also, the person accused must be a specific individual, rather than a general group of people. This particular person must be addressed by the creator. In certain situations, it may not be an act, but it may contain elements of action. For example, dating a prostitute (the meaning of actions, intercourse with prostitutes), extortionists (in which the meaning of blackmailing acts), and fraudsters (in which there are deceptive acts). The word can be considered to carry out certain actions so that said words can be qualified as defamation. Even though it does not directly or explicitly mention certain forms of action, it contains certain ideas of actions and the accusation of the act has embarrassed the intended person. It is also important regarding the alleged action, which must be in the form of an act, which according to the community's judgment is a disgraceful act. In general, the word "get together kebo", dating a prostitute, eating people's money, carries embarrassing shame. ${ }^{15}$

\section{REASONS TO ELIMINATE "WITHOUT LEGAL RIGHTS" CRITERION}

A criminal charge can be removed by two reasons: forgiving and justification. Forgiving reasons are reasons that eliminate mistakes from the perpetrator. Because it concerns the wrongdoing of the perpetrator, the reason for the criminal offense concerns only to the perpetrator's personal self. Meanwhile, the justification reasons are the reasons that eliminate the lawlessness of the deed. Because it concerns deeds, this reasoning applies to all those who commit the act. ${ }^{16}$ The reason for removing the criminal charge requires two different forms of court decisions. The first is an acquittal decision (vrijspraak), and the second is a decision that provides no objection from all lawsuits (ontslag). An acquittal decision is a decision concerning the nature of being against the law of the perpetrator/defendant being abolished, or concerning the element of his criminal act (in this case the objective element) which was abolished. Whereas a verdict is free from all lawsuits is a decision considers if the mistake (as a subjective element) of the perpetrator/defendant can be abolished. ${ }^{17}$

If the reason for the justification exists or does not constitute an act against the law, and the alteration is a core part of the offense, then the decision is free. Whereas, if there is no mistake or there is no forgiving foundation, then the decision is released from all lawsuits. ${ }^{18}$ In the justification reason, what must be proven is whether the nature of being against the law of the perpetrator is indeed lost, as determined by an unwritten or written law. The purpose of this is so that the act can indeed be justified. Pompe distinguishes the notion of breaking the law into two categories: formal and material. According to Pompe, the term is clearly "against the law, not written in the law. In other words, Pompe views "against the law" as against material law. This also

\footnotetext{
15 Adam Chazawi, supra note 2 at 86.

16 Hamdan, Alasan Penghapus Pidana Teori dan Studi Kasus (Bandung: Refika Aditama, 2012).

17 Ibid at 29.

18 Andi Hamzah, Asas-Asas Hukum Pidana di Indonesia dan Perkembangannya (Medan,: Sofmedia, 2012).
} 
includes actions that are contrary to unwritten law and contrary to propriety, which is considered against the law. Whereas formally, against the law is interpreted as contrary to the law. If an action has matched the offense formula, it is usually said to be against the law formally.

In criminal law, justification reasons are divided into two. First, criminal law addresses the reasons for general justification. That is the reason for criminal offenses that are generally applicable to every crime and referred to in Article 44, 48, up to Article 51 of the Criminal Code. The second includes specific justification reasons. That is the reason for the criminal offense that applies only to certain criminal acts. For example, Article 112 of the Criminal Code, Article 221 paragraph (1) of the Criminal Code, and 310 paragraph (3) of the Criminal Code. ${ }^{19}$ The Law on Information and Electronic Transactions does not explain what is meant by an element without rights. As described previously, every act that is prohibited must have an illegal nature. Some are expressly stated as elements in an article, while others are implied. For example, the term "against the law" (wederrechtelijk) is firmly used in Articles 167, 168, 335 (1), 522, and in other terms: "without having the right to it" (Article 303, 548, 549); "Without permission" (zonder verlof) (Article 496, 510); "By exceeding its authority" (Article 430); "Without regard to the methods determined by general regulations" (Article 429). ${ }^{20}$

It is often difficult to distinguish whether something in the formula is an element or not. In this case, if there is an offense in the element then it should be an acquittal decision. Examples of offense formulations in Article 551 of the Criminal Code (KUHP) states that whoever is without rights walking or driving on land which the owner clearly uses is prohibited, is threatened. Clearly the words "without rights" here is a core part of the offense, which if it cannot be proven, the decision applies acquittance. It is similar to if there are words like Article 152 paragraph (1): "without necessity", the decision will be acquitted too. According to Chazawi, what is meant by "without rights" in Article 27 paragraph (3) of the ITE Law is that it is against the law, despicable, or inappropriate. That is, before distributing, transmitting and making accessible information and/or electronic documents, the maker realizes that he is not entitled to do so. Based on the description, it can be concluded that in the "no rights" element, Article 27 paragraph (3) of the ITE Law, it is inherent in the lawless nature must be proven. According to the statement from the $\mathrm{MvT}$, every element of deliberation in the formulation of a crime is always directed at all elements behind the intentional saying. So "intentional", as Article 27 paragraph (3) of the ITE Law states, suggests someone is aware that the act of distributing, transmitting, and making access to electronic information and/or Electronic documents as an act carried out "without rights".

The ITE Law does not explain what is meant by elements without rights and in terms of what a person is said to have the right to distribute transmit, or make accessible Information, Electronic Documents that contain, defamation. Because of this ambiguity, it is necessary to refer to the Decision of the Constitutional Court Number 50/PUU-VI/2008, which states that the constitutionality of Article 27 paragraph (3) cannot be released from the legal norms written in Article 310 and Article 311 of the Criminal Code. Based on the Constitutional Court Decision Number 50/PUU-VI/2008, Article 27 paragraph (3) of the ITE Law cannot stand alone. Article 310 paragraph (3) of

19 Sudarto, Ilmu Hukum Pidana (Jakarta: PT Eresco, 1987).

20 PAF Lamitang, Dasar-Dasar Hukum Pidana Indonesia (Bandung: Sinar Baru, 1990). 
the Criminal Code states that not a defamation or written defamation, if a bright deed is carried out in the public interest or forced to defend himself. ${ }^{21}$

Article 310 paragraph (3) of the Criminal Code states that a person cannot be convicted if the defamation is carried out in the public interest and is forced to defend themselves. This has an understanding that if the elements in Article 310 paragraph (1) or paragraph (2) of the Criminal Code are fulfilled, but the defamation act is carried out in the public interest or forced to defend itself, then it is necessary to remove the nature of being illegal and the defamation act cannot be punished. Some of the decisions interpreted the element without rights are as follows:

\section{The case of Prita Mulyasari (Decision Number 1269/Pid.B/2009/PN.Tng)}

The District Court in his ruling stated that Defendant Prita Mulyasari was not proven legally, nor was he convincingly guilty of committing a crime as the first indictment, second, and third. The Defendant was freed from all charges. In this case, the Panel of Judges assessed the element without rights in Article 27 paragraph (3) of Law Number 11 Year 2008 concerning Information and Electronic Transactions. This is stated on page 59 of Decision Number 1269/Pid.B/2009/PN.Tng:

"That which is a problem in distributing, transmitting and making access to Electronic Information and/or Electronic Documents is that the defendant has the right or not;"

"Considering, that the email sent by the defendant was in the public interest, then according to Article 310 paragraph (3) of the Criminal Code the email of the defendant was titled "Omni International Fraud of Alam Sutera Hospital Tangerang" whose contents included "I also informed Dr. Hengky also practiced at the RSCM, I did not say the RSCM was bad but more careful with this doctor's medical treatment and the response of Dr.Grace who he said was the person in charge of complaint my, not professional at all and no manners and ethics regarding customer service " not including notions; ${ }^{22}$

insulting" The Panel of Judges believes that the defendant's e-mail as described above does not contain insults and/or defamation, because the sentence is criticized and in the public interest so that the public is spared from hospital practices and/or doctors who do not provide good medical services to people who are sick who expect to recover from the disease ${ }^{123}$

\section{The case of Diki Chandra (Decision Number 1190/Pid.B/2010/PN.Tng)}

In this case, the Panel of Judges considered the element without rights aimed at the rightful people who distribute and make accessible information and electronic transactions may not be convicted. In addition, understanding without rights, in this case, also refers to Article 310 paragraph (3) of the Criminal Code, where there is a reason for eliminating the nature of violating the act of criminal defamation as formulated in the decision as follows:

"Considering, that the ITE Law does not provide information or an explanation of what or with what conditions, the person who distributes, transmits, or makes accessible electronic information whose contents are insulting has the right to do so that it must be sought from sources of legal

${ }_{21}$ Supriadi Widodo Eddyono, Problem Pasal Pencemaran Nama Baik (Jakarta: ELSAM, 2014).

22 District Court Decision No. 1269/Pid.B/2009/PN.Tng at 59.

23 Ibid. 
insult in Chapter XVI of book II of the Criminal Code which derives from defamation (Article 310 KUHP) because every form of humiliation is always defamatory and respectful of people ${ }^{124}$

"Considering, that in the case of defamation there is a reason for the elimination of acts against the law (Article 310 paragraph (3) of the Criminal Code), criminal acts (Article 310 paragraph (3) of the Criminal Code), defamation is not punished if carried out in the public interest or because of forced to defend themselves and these two conditions that cause the creator has the right to distribute, transmit, make accessible electronic information even though the contents are insulting. ${ }^{25}$

The meaning of the word in the public interest and forced to defend itself (the defendant who did the defamation act) is also not explained in normative jurisdiction in Article 310 of the Criminal Code and Article 27 paragraph (3) of the Electronic and Information Law. According to the Big Indonesian Language Dictionary (KBBI), interest comes from the word "important" which means it is very necessary and preferred. While what is meant by "general" is the whole wider community. If interpreted in the language of public interest, this is something that is very necessary and prioritized by the whole wider community.

Based on Article 1 number 5 of the Presidential Regulation Number 30 of 2015, the public interest is the interests of the nation, state, and society that must be realized by the government and used as much as possible for the prosperity of the people. Unlike CST Kansil who argues that the public interest as follows; (a) the regulatory body State legislation, such as the state, state sheets, civil servants, government regulations, and so on; and (b) the general interests of each human soul includes body, independence, honor, and property. According to Chazawi, to be able to submit reasons for the public interest, besides being very necessary and not solely for the personality of the creator himself, also includes the benefit of others (general). Also, the content submitted must be correct. ${ }^{26}$ The ratio of provisions for the public interest in Article 310 paragraph (3) of the Criminal Code is that legal protection for the public interest is more important than legal protection for private people. ${ }^{27}$

Article 27 paragraph (3) of the ITE Law and Article 310 paragraph (3) of the Criminal Code also does not explain normatively and juridically what act can be forced to defend itself. Is defending himself, as intended in 49 paragraph (1) of the Criminal Code, or should one defend himself in another sense? If further examined, there are some differences between defending themselves in Article 49 paragraph (1) of the Criminal Code and Article 27 paragraph (3) of the ITE Law in conjunction with Article 310 paragraph (3) of the Criminal Code.

Based on the description above, there are several differences between forced defense as intended in Article 49 paragraph (1) of the Criminal Code and Article 310 paragraph (3) of the Criminal Code. First, one of the conditions of forced defense is that the defense is limited to the body, the honor of morality, and property. R Soesilo comments regarding the explanation of Article 310 of the Criminal Code, insulting 'is' attacking one's honor and good name. In addition, it also states that those who are attacked usually feel 'ashamed' 'Honor' which is attacked here is only about honor about 'good name', not 'honor' in the sexual field, honor that can be defiled because of

${ }^{24}$ District Court Decision No. 1190/Pid.B/2010/PN.Tng.

25 Ibid.

26 Adami Chazawi, supra note 2 at 273.

27 Ibid at 102. 
offense by the members of the genitals in an environment of sexual desire. ${ }^{28}$ So, an attack on the body or decency, in Article 49 paragraph (1) of the Criminal Code, cannot be said to be an attack on the good name as stipulated in Article 310 paragraph (3) of the KUHP means that Article 49 paragraph (1) of the Criminal Code cannot be used as a guideline for forced defense attacked by his good name. Second, one element of forced defense in Article 49 paragraph (1) of the Criminal Code is that which is defended by oneself or others while in Article 310 paragraph (3) of the Criminal Code the defense is forced to defend the perpetrators themselves who feel polluted by their good name. Referring to the opinion of Chazawi, who stated: "Attacks that are against the new law can be justified as self-defense, in defense of noodweer if the unlawful attack occurred from that moment. But self-defense according to Article 310 paragraph (3) of the Criminal Code can be done not when an offensive occurs. ${ }^{29}$ Therefore, in Article 49 paragraph (1) of the Criminal Code, attacks that are against the new law can be justified as self-defense if they occur at that time. While forced to defend themselves as stipulated in Article 310 of the Criminal Code can also be done at that time.

Forced defense as intended in Article 49 paragraph (1) of the Criminal Code cannot be used as a guideline of the definition of forced defense by the party attacked by its good name as stipulated in Article 27 paragraph (3) of the ITE Law in conjunction with Article 310 paragraph (3) of the Criminal Code. According to Chazawi, to be able to present reasons for self-defense two conditions are needed. First, there must be an action in the form of an attack by another person that is against the law. Second, the maker must be able to prove the allegations.

The uncertainty of justification for the elements without rights or reasons that can eliminate the lawlessness of an act is in Article 27 paragraph (3) of the ITE Law. There is no explanation to judge in the public interest nor are they forced to defend themselves, which can cause uncertainty in law enforcement. Thus, in practice, it is very difficult to assess the elements without rights, and it becomes left to the interpretation of the judge. Therefore, an explanation of the concept is needed for the public interest itself as well as detailed boundaries, so that the purpose of legal protection in Article 27 paragraph (3) of the ITE Law is not misused.

\section{CONCLUSION}

ITE Law does not provide detailed definitions of corruption and defamation, and there are no clear limits on what words may or may not be written. For example, the feeling for a good name is being attacked is subjective to the victim. More objective criteria are needed regarding actions that can be qualified as criminal acts of defamation through electronic media in order to achieve legal objectives, namely justice, legal certainty, and expediency. This sense of criteria is also necessary for assessing whether electronic information or electronic documents credit a defamation charge. First, the identity of the person insulted in electronic information and documents that have insulting content or defamation must be clearly addressed to the victim, even if it is a username that is not a real name. Secondly, information or electronic documents that have content of insult or defamation can be addressed to a natural person and legal person. Thirdly, the case must be assessed, based on the content and context in which it exists,

28 Nanda Yoga, "Prinsip-Prinsip Hukum tentang Tindak Pidana Penghinaan dan Pencemaran Nama Baik dalam Perspektif Perlindungan Hak Asasi Manusia” (2017) Volume 32 Issue 1.

29 Adami Chazawi, Hukum Pidana Positif Penghinaan (Surabaya: ITS PRESS, 2009). 
with particular focus on the language and habits that live in the community. Finally, information or electronic document can be qualified as defamation if it contains charges of committing an act.

In the "indefinite" element in Article 27 paragraph (3), it states the nature to which the law should be proved. The "no right" element is intended for the person who is entitled to criminal offense to be defamatory. The ITE Law does not explain in the case of a person being said to be entitled to criminal offense by electronic media. Therefore, it should refer to Articles 310 and 311 of the Penal Code. Article 310 Paragraph (3) of the Penal Code states that a person cannot be convicted if the act is done in the public interest and to defend himself. However, the ITE Law and the Criminal Code do not provide a normative juridical explanation of public interest, nor are they forced to defend themselves.

The definition of defamation in Article 27 paragraph (3) of the ITE Law is subjective. In this case, the law enforcers must note that the article is not misused. Law enforcement officials cannot directly state that electronic information or electronic document is categorized as insulting or defamation if only based on the subjective feelings of the victim. But it must also be balanced with more objective criteria, such as clarity of identity of whom the defamation words are intended for. Law enforcers must also be careful and able to understand the development of language and habits that live in the surrounding community. Because without more objective criteria, the purpose of legal protection provided through Article 27 paragraph (3) of this ITE Law can be misused. It is necessary to add a detailed explanation of the inherent element of being against the law as justification for the element of "no rights". In addition, clear boundaries are needed for concepts in the public interest and forced to defend themselves (the defendant of the defamation act).

\section{REFERENCES}

Ali, Mahrus. Hukum Pidana Positif Penghinaan (Edisi Revisi) (Malang: Media Nusa Creative, 2016).

-_C_- "Pencemaran Nama Baik melalui Sarana Informasi dan Transaksi Elektronik (Kajian Putusan MK No. 2/PUU-VII/2009”, (2010) Volume 07 Issue 06.

Anggara., Komarudin, Asep., \& Eddyono, Supriadi Widodo. Menimbang Ulang Pasal 27 ayat (3) UU ITE dalam putusan pengadilan (Jakarta: Institute for Criminal Justice Reform (ICJR), 2016).

Chazawi, Adami. Hukum Pidana Positif Penghinaan (Surabaya: ITS PRESS, 2009).

Eddyono, Supriadi. Problem Pasal Pencemaran Nama Baik (Jakarta: ELSAM, 2014).

Fajar Indrawan, Aditya. "Pengacara keberatan dengan dakwaaan JPU: Posan Yusniar tak sebut nama orang", (13 July 2018), online: <diakses dari https://news.detik.com/berita/d-3341329/pengacara-keberatan-dengandakwaan-jpu-posan-yusniar-tak-sebut-nama-orang>.

Hamdan. Alasan Penghapus Pidana Teori dan Studi Kasus (Bandung: Refika Aditama, 2012).

Hamzah, Andi. Asas-Asas Hukum Pidana di Indonesia dan Perkembangannya (Medan,: Sofmedia, 2012).

Manage qolbu. "Makalah Hukum Pidana", (12 July 2018), online: 〈http:/ /wwwqolbu27.blogspot.com/2010/06/tindak-pidana-terhadap-

kehormatan.html. 
PAF Lamitang. Dasar-Dasar Hukum Pidana Indonesia (Bandung: Sinar Baru, 1990).

Prodjodikoro, Wirjono. Tindak Pidana Tertentu di Indonesia (Bandung: Refika Aditama, 2003).

Sitompul, Joshua. Cyberspace, cybercrimes, cyberlaw (Jakarta: PT Tata Nusa, 2012).

Skripsi Fakultas Hukum Unhas. "Tinjauan Yuridis terhadap Tindak Pidana Penghinaan" (2014).

Sudarto. Ilmu Hukum Pidana (Jakarta: PT Eresco, 1987).

WartaBromo. "Sempat Diputus Bersalah, Kades Sumbergedang Bebas dalam Dugaan Pencemaran Nama Baik di FB", (13 July 2018), online: 〈https://kumparan.com/wartabromo/sempat-diputus-bersalah-kadessumbergedang-bebas-dalam-dugaan-pencemaran-nama-baik-di-fbWidodo>

Yoga, Nanda. "Prinsip-Prinsip Hukum tentang Tindak Pidana Penghinaan dan Pencemaran Nama Baik dalam Perspektif Perlindungan Hak Asasi Manusia" (2017) Volume 32 Issue 1. 